\title{
Effects of Time-Controlled Grazing on Runoff and Sediment Loss
}

\author{
By \\ Gholamreza Sanjari $^{\mathrm{A}, \mathrm{B}, \mathrm{E}}$, Bofu $\mathrm{Yu}^{\mathrm{D}}$, Hossein Ghadiri ${ }^{\mathrm{A}}$, Cyril A. A. Ciesiolka ${ }^{\mathrm{C}}$, Calvin W. Rose

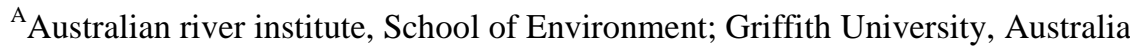 \\ ${ }^{\mathrm{B}}$ Research Institute of Forests and Rangelands, Tehran, Iran \\ ${ }^{\mathrm{C}}$ Department of Natural Resources and Mines, Toowoomba, QLD, Australia \\ ${ }^{\mathrm{D}}$ School of Engineering, Griffith University, Australia \\ ${ }^{\mathrm{E}}$ Corresponding author; email: G.Sanjari@griffith.edu.au
}

\begin{abstract}
The time-controlled rotational grazing (TC grazing) has become popular in Australia and elsewhere in the world to provide graziers and ranchers with a relatively higher productivity over traditional practices. However, this grazing system, which involves short periods of intensive grazing, has raised concerns about the sustainability of such a practice and its environmental impacts on water and soil resources, and ecosystem health generally. To address some of the issues, a runoff experiment at the catchment scale was established on the grazing property of Currajong in the south-east region of Queensland, Australia, to investigate the effects of the two grazing systems (continuous and Timecontrolled) on runoff and sediment generation from 2001 to 2006.
\end{abstract}

The results indicate that sediment loss was reduced significantly under TC grazing when compared with continuous grazing irrespective of the size of runoff events. This effect was more pronounced in the catchments with soils of gentler slopes and greater depths. The reduction in soil erosion was achieved despite the fact that the increase in ground cover under TC grazing had little effect on runoff coefficient or runoff volume. Decrease in runoff in relation to the increase in surface cover only occurred for small events whereas for large rainfall events, runoff was generated irrespective of the level of ground cover.

The results of this study showed that ground cover is a key driver in reducing sediment concentration, resulting in a significantly lower sediment loss under TC grazing. In the study area a minimum of $70 \%$ of surface cover as threshold appeared to be needed to efficiently protect the soil surface from erosive forces of rain and runoff and to control soil erosion. The results also indicate that TC grazing has a superior capability to produce and maintain a higher level of ground cover (up to 90\%) over continuous grazing (up to $65 \%)$. The long rest periods in TC grazing is seen as being the major contributor to soil and pasture recovery after the intensive defoliations by grazing animals, leading to an increase in above ground organic material thus surface cover over time.

Key words

Rainfall, erosion, ground cover, pasture, Queensland, Traprock, 


\section{Introduction}

Grazing systems have been shown to greatly affect vegetation cover which is the primary layer for soil protection against water erosion. Decrease in vegetation cover increases the exposure of soil surface to raindrop impact (Busby and Gifford 1981), reduces soil organic carbon and aggregate stability (Johnston 1962; Warren et al. 1986b; Proffitt et al. 1995), and enhances surface crust which in turn increases runoff and sediment loss (McGinty et al. 1979; Mwendera and Saleem 1997). On the contrary, any increase in vegetation cover has frequently been reported to reduce soil erosion and sediment transport (Francis and Thornes 1990; Bajracharya and Lal 1998; Boix-Fayos et al. 1998; Pan and Shangguan 2006).

Grazing continuously leads to surface soil compaction with associated loss of pore structure and connectivity reducing infiltration capacity (Gifford and Hawkins 1978; Greenwood and McKenzie 2001). For this reason in continuous grazing, as the stocking rate increases, runoff and soil loss increases (Alderfer and Robinson 1947; Rhoades et al. 1964; Rauzi and Hanson 1966).

Introduction of rotational grazing system in 1960s, as an alternative to continuous grazing, resulted in some improvement in soil and surface hydrology, through the enhanced organic materials over the periods of animal exclusion. Two early works on runoff and soil erosion under rotational grazing (McGinty et al. 1979; Wood and Blackburn 1981) showed that the application of rest periods to pastures significantly reduced runoff and soil loss as compared with continuous grazing and even non-grazed areas. Warren et al. (1986a) who examined Intensive Short Period Grazing under rotational system in Texas, USA, found some soil recovery to occur during a 30 days rest period. This was evident from the higher infiltration rates and lower sediment loss recorded at the end of the rest periods compared with the beginning of them. In another study on soil hydrologic aspects, Weltz and Wood (1986a; b) showed significant increase in infiltration rates and decline in soil loss under short grazing systems compared to the other treatments.

Unlike the positive reports on the effects of the short period intensive rotational grazing on runoff and soil erosion, reduction in soil hydraulic conductivity (Ksat) as well as increase in soil bulk density (BD) have been reported (Bryant et al. 1989; Dormaar et al. 1989). Despite the above inconsistency, the rotational grazing system, commonly known in Australia as time-controlled (TC) grazing, has been increasingly adopted by graziers, while the sustainability of such practice is under question and its effects on runoff control and soil erosion have not been fully investigated. To address the concerns with how TC grazing system affects surface hydrology and soil erosion variables, a catchment runoff experiment was set up under a large scale commercial livestock property in southeast Queensland, Australia. 
This paper reports on the results of a 6 year period of data collected from 3 small catchments treated by the two systems of TC and continuous grazing. Monitoring of the changes in runoff and sediment loss through time under the two grazing practices is based on the assumption that grazing systems influence runoff and sediment by affecting soil above/below ground organic materials. The hypothesis of this research is that TC grazing, which incorporates long periods of rests, increases vegetation cover therefore results in a decrease in runoff and soil loss.

\section{Methods and materials}

\section{Field site}

The research was conducted at "Currajong”, a grazing property $40 \mathrm{~km}$ west of Stanthorpe in the semi-arid region of south-east Queensland, Australia (28 $33^{\circ}$ S, $151^{\circ} 33^{\prime} \mathrm{E}$, altitude $675 \mathrm{~m}$ ) (Fig 1). The area, known locally as Traprock, is located in the catchment of the MacIntyre Brook at the northern headwaters of the Murray Darling basin. It is drained by Treverton Creek, as the first immediate stream into Coolmunda dam.

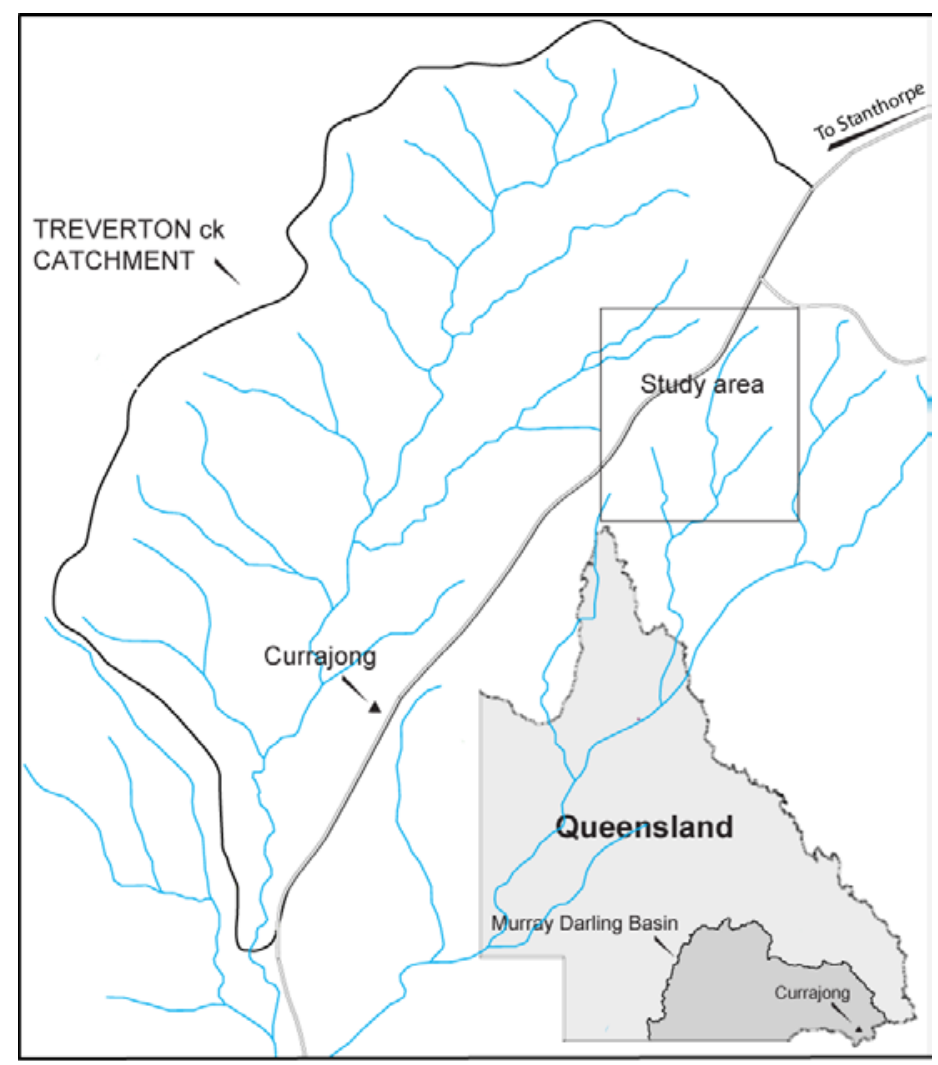

Fig. 1. Location map of the study area 


\section{Vegetation, climate and soil}

The long term (119 years) mean annual rainfall for the property of “Currajong” is 645 $\mathrm{mm}$, with a summer dominant rainfall of around 70 percent, which falls in six months from October to March. There are two recognizable and discernible periods of wet and dry in the region. The rain in the wet season (October to March) is characterized by relatively high frequency of medium to large events of short (thunderstorms), and long (cyclonic depressions) durations. In the dry season (April to September), there are smaller events, both in magnitude and intensity associated with frontal depressions.

The records of long term data (1889 - 2007) were extracted by SILO (Data Drill dataset) for the study area using original data from surrounding areas. The Data Drill accesses grids of data derived by interpolating the Australian Bureau of Meteorology's station records. The meteorological records were spatially interpolated with the spline and kriging techniques (Wahba and Wendelberger 1980; Hutchinson 1995; Jeffrey et al. 2001).

The soil of the study area originates from a mixture of highly deformed sandstone, mudstone, inter-bedded conglomerate, limestone and volcanic soils/rocks (Maher 1996). The soil is shallow to moderately deep with a hard setting brown to dark clay loam (Table 1) underlined by a bleached A2 horizon. The soil analysis of the study area (Sanjari et al. 2008) shows the following properties for the surface soil $(0-10 \mathrm{~cm})$ : bulk density 1.2 $\mathrm{g} / \mathrm{cm}^{3}$; pH 5.6 and EC $0.06 \mathrm{mS}$ (1:5 water suspension); soil organic carbon 26 ton/ha (Walkey and Black); $\mathrm{NO}_{3}{ }^{-} 0.6 \mathrm{~kg} / \mathrm{ha}$ (2M KCL extraction) and extractable $\mathrm{P}$ of $17 \mathrm{~kg} / \mathrm{ha}$ (Colwell bicarbonate extractable phosphorus).

Geology comprises part of the Warroo land system, generally referred to as Traprock. The study site, in the areas of Treverton Creek headwater, is visibly eroded by channel incisions and re-incision of alluvial deposits in valley floors and sheet erosion due to the lack of vegetative cover. The incisions by channels of the drainage system and reincisions of the sediment are naturally occurring geomorphological processes common in the region. It appears that the anthropocentric impositions on the landscape have sped up the natural processes in the sculpturing the landscape, leaving insufficient time for natural regeneration to take place. The geomorphologic characteristics of the lands have been described in details by Wills (1979).

Vegetation in the study area is characterized by Eucalypt open woodland with understorey native and neutralized perennial grass species. The on ground plant community is dominated by a desirable species known as Queensland blue grass [Dichanthium sericem (R. Br.) A. Camus]. The next plants, in the order of dominance, includes a few native species of Wiregrass (Aristida $s p$ ) that are known to be less desirable. Amongst the remaining species, Silky browntop [Eulalia aurea (Bory) Kunth], Wallaby Grass [Danthonia tenuior (Steud.) Conert] and Hairy Panic [Panicum effusum R.Br.], Pitted blue grass [Bothriochloa decipiens (Hack.) C.E.Hubb.] and Digitaria 
[Digitaria breviglumis (Domin) Henrard] exist, but they have a low frequency in the plant composition.

\section{Treatments}

The three small catchments used in this experiment ranged in size from 3.2 to 8 hectares and were fully instrumented to record rainfall and runoff (Table 1).

Table 1. General characteristic of the experimental catchments

\begin{tabular}{c|cccccccc}
\hline $\begin{array}{c}\text { Name of } \\
\text { Catchment }\end{array}$ & Area & $\begin{array}{c}\text { Slope } \\
\%\end{array}$ & \multicolumn{2}{c}{$\begin{array}{c}\text { Hill slope } \\
\text { shape }\end{array}$} & & Aspect & \multicolumn{3}{c}{ Soil size fraction (\%) } \\
\hline C1 (TC grazing) & 8 ha & 11 & Convexo-concave & $\mathrm{N}$ & 35.2 & 30.6 & 34.2 \\
C2 (TC grazing) & 3.4 ha & 16 & Rectilinear & $\mathrm{N}$ & 29.5 & 31.4 & 39.1 \\
C3 (Con. grazing) & 7.5 ha & 11.5 & Convexo-concave & $\mathrm{N}$ & 34.6 & 33.0 & 32.4 \\
\hline
\end{tabular}

One of the three catchments $\left(\mathrm{C}_{3}\right)$ was grazed continuously over the study period with a constant stocking rate of 1.6 DSE (Dry Sheep Equivalent)/ha. This grazing intensity is considered normal in the region and exerts a light to moderate pressure on the pasture. The other two catchments $\left(\mathrm{C}_{1}\right.$ and $\left.\mathrm{C}_{2}\right)$ were grazed under TC grazing system with high stocking rates of differing grazing/rest periods depending on feed availability and the rate of grass growth in the paddocks (Table 2). Much care was taken to keep the total DSE.day/ha (DDH) similar between the two grazing systems which is an important initial assumption for all the comparisons between the treatments.

Table 2. Stocking details for the two grazing treatments

\begin{tabular}{lcccc}
\hline $\begin{array}{c}\text { Grazing } \\
\text { Treatments }\end{array}$ & $\begin{array}{c}\text { Grazing periods } \\
\text { (days) }\end{array}$ & $\begin{array}{c}\text { Rest periods } \\
\text { (days) }\end{array}$ & $\begin{array}{c}\text { SR } \\
\text { (dse/ha) }\end{array}$ & $\begin{array}{c}\text { DDH } \\
\text { dse.day/ha }\end{array}$ \\
\hline Time-controlled & $14 \pm 9 \ddagger$ & $(101 \pm 60) \ddagger$ & $12.6 \pm 6 \ddagger$ & 3608 \\
Continuous & 365 & 0 & $1.6 \pm 0.2$ & 3529 \\
\hline
\end{tabular}

‡-Means \pm SD; $\quad$ SR- Stocking rate; $\quad$ DSE- Dry Sheep Equivalent

$\mathrm{DDH}$ - Number of dse days per hectare over the whole study period

\section{Field instruments}

During the study a wide range of field instruments were used including: $3 \mathrm{H}$-flumes, 6 storage raingages, 1 automatic weather station and 5 pluviometers with associated loggers. The modified Sun Dimas H-flumes (Bermel 1950) of different widths and heights, were constructed at the exit end of the three catchments. The flumes were equipped with flow measuring and sample collection instruments. The height of the 
runoff flowing through the flumes was recorded in mm using Greenspan pressure transducer positioned in stilling wells. A pluviometer was connected to each logger at the flumes to record rainfall intensity at 1 minute intervals. The surface runoff, passing through the flumes, was sampled using automatic pumping samplers capable of holding up to 50 water bottles. The pumping interval was set at 3 minutes during the thunderstorm season and at 5 minutes for remainder of the time. The operation was activated by a float switch positioned in the stilling well of the flume and sampling began as soon as the flow height reached a predefined level. A bilge pump, submerged in a very small mixing pond at the outlet of the flumes, was triggered to facilitate this action.

For a precise estimation of the rainfall, all the tipping buckets used in the pluviometers went through calibration and error estimation procedure. Any high flow rate could produce more tips per unit time, thus if the bucket is overfilled it can hold a greater volume of water than is required for breaking the static equilibrium of the bucket (Calder and Kidd 1978; Giboire et al. 2003). The errors caused by the overfilling of the buckets at high flow rates were eliminated using a third order polynomial equation relating the tipping frequency to the bucket volume.

While rainfall intensity is a continuous variable, tipping bucket technology produces discrete values capable of creating a source of relative error. For this reason a fixed absolute sampling errors exists which is controlled by bucket volume, catchment area of the gauge, and sampling interval (Yu et al. 1997). The measurements carried out on the pluviometers tipping buckets used in the study area showed the acceptable absolute sampling error of $8.7 \%$ for rainfall intensity if a relative error of no more than $10 \%$ is desirable.

\section{Event categories and definitions}

In this study, a rainfall event was defined as any amount of rainfall recorded by the loggers separated by dry periods of at least 6 hours but not all rain events necessarily produced runoff. The duration of a rainfall-runoff event was defined as the time (min) from the start of rainfall contributing to the runoff event, until the end of the water flowing through the flumes.

To explore the effect of ground cover on runoff generation and sediment loss, runoff events were grouped into two categories of 'small' and 'large' events based on their rainfall depths. Apart from rainfall amount, it's well known that rainfall intensity also play an important role in the hydrological responses of areas to rainfall. Therefore inclusion of both variables provides a more accurate basis for grouping the events however due to some limitation, only rainfall depth was used to categorize the events.

In any catchment scale experiment using natural rainfall events such as ours, the number of runoff events is much lower than a plot scale experiment. Inclusion both rainfall depth and intensity in this experiment not only required more groups to be established but also would leave out some of the events that don't fall into any of the groups due to the 
predefined ranges of rainfall depth and intensity. Such a limitation would greatly reduce the number of events in each category which significantly increases the amount of error when relating the cover levels to runoff and soil loss.

A brief introduction on rainfall erosivity (EI30) in relation to rainfall depth for this study (Fig 2) revealed a significant correlation $(r=0.85, p<0.01)$ between the variables. Such a relationship is based the following equation which was developed for the study area.

$\mathrm{EI} 30=\mathrm{aP}^{\mathrm{b}}=1.21 \mathrm{P}^{1.44}$

where $\mathrm{E}$ is the total kinetic energy per unit area for a storm (MJha-1) (Brown and Foster 1987); I30 is peak 30-minutes intensity (mmhr-1) and $P$ represents the total rain for the storm. The value of $b$ in literature is reported to be $1.49 \pm 0.25$ (on one SD) in temperate region of Australia (Yu and Rosewell 1996a; Yu and Rosewell 1996b) as well as 0.89 to 1.88 in north and south Poland (Banasik et al. 2001).

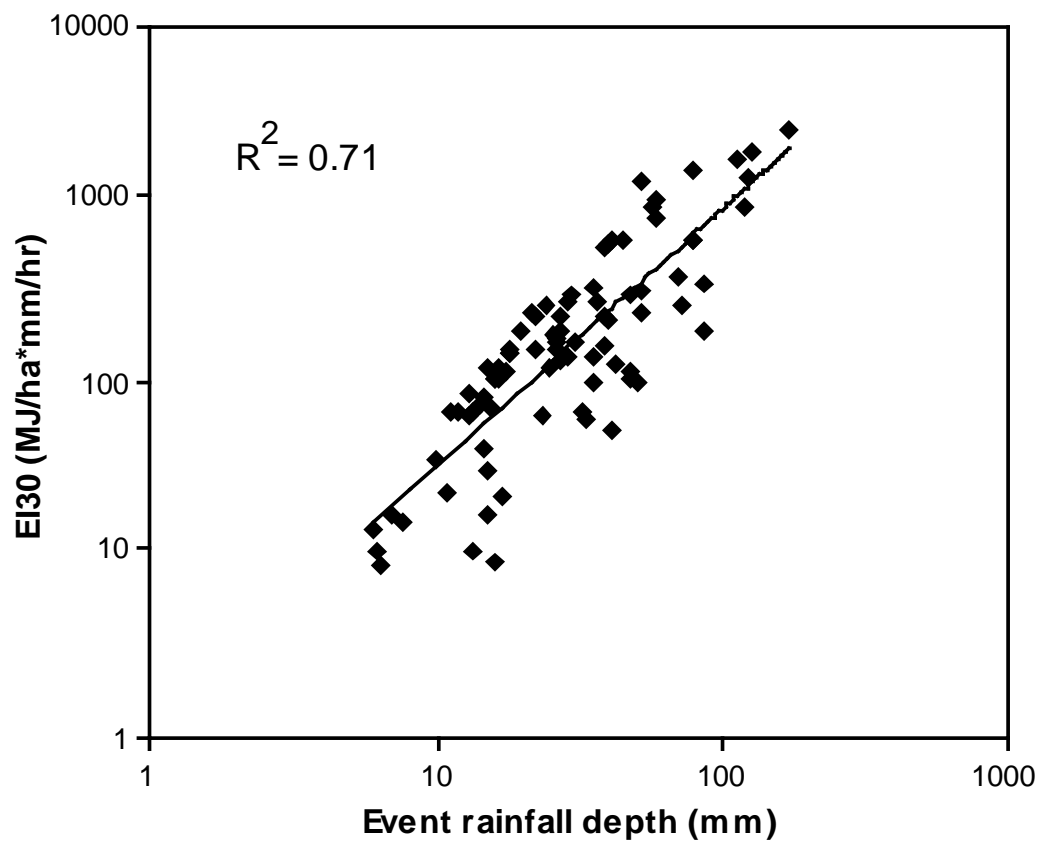

Fig. 2. Rainfall erosivity in relation to rainfall depth for the runoff events in the study area

In figure 2, although the effects of rainfall intensity on EI30 is obvious, rainfall depth however appeared to have a greater effect on the erosive forces of rainfall on soil erosion in the study area. The significant correlation between amounts of rain and EI30 suggests under the aforementioned limitation on the available number of runoff events, rainfall depth could be a reliable surrogate to the combined rainfall depth and intensity to classify the runoff events into the different groups in our study. 
The categorization of runoff events using rainfall depth provided the experiment with adequate number of events in each category allowing a reliable analysis. The thresholds defining the two rain size categories were determined based on the equal contribution of the small and the large events to total amount of rain over the course of the study. In other words, each group of small or large events contributes one half of the total rainfall.

To determine these thresholds, runoff events were arranged in ascending order in terms of their associated rain depth. Event rainfall was then accumulated from the rain amount of the smallest event to the largest. The size of the rain event that its corresponding cumulative rain was about half of the total rain was introduced as the rain threshold between small and large events. This rainfall threshold turned out to be about $50 \mathrm{~mm}$ for all the three catchments. Incidentally, the $50 \mathrm{~mm}$ threshold to separate large and small events coincides with the definition of a 'heavy storm' commonly used in meteorology.

\section{Runoff depth and sediment loss estimation}

The water samples taken from the outlets of the flumes were transferred to the erosion laboratory in Nathan Campus of Griffith University for analysis. Sediment loss was estimated from the product of the sediment concentration and runoff flow rate. A series of computer programs were used to retrieve data and calculate total rain, rainfall intensity, runoff rate and total runoff for each event.

\section{Ground cover}

Ground cover is one of the main attributes of vegetation in grazing practices often recognized as a reliable indicator of soil protection and sustainability. It provides the soil surface with an effective organic layer to absorb raindrop energy, reduce runoff velocity and decrease compaction by dissipating animal hoof action on the soil underneath. Ground cover refers to any non-soil materials on the ground that protects the soil from raindrop impact (McIvor et al. 1995). The definition is originally based on the commonly used method of aerial plant cover (Greig-Smith 1983) which measures the proportion of the ground occupied by perpendicular projection of the aerial parts of plants but includes all non soil components (living/dead organic material and stone).

Ground cover in the study area was measured using visual estimation (Zhou 1998) over the rest periods and prior to the next grazing cession (at least four times a year) at 33

permanent sampling points distributed throughout the catchments using a square $0.25 \mathrm{~m}^{2}$ quadrate . Further records were taken from 2004 onwards and the ground cover measurement was fixed to 1.5 month increments towards the end of the study period. Photographs were also taken from selected permanent points under shorter intervals of 7 to 14 days depending on the time of events and date of field site visits. The bare ground percentage, computed from the photographs was combined and correlated to the data measured by the visual method to produce a shorter time interval of ground cover values closer to the time of runoff events. In some cases it was necessary to interpolate between 
two consecutive values estimating a ground cover percentage for the date of the runoff event.

\section{Data analysis}

Based on the assumption that grazing treatments affect vegetation cover and hence runoff and soil loss through time, a sequential series of data analyses were carried out. The first method compares the overall changes in runoff and sediment for all the catchments from the first period of the study (2001 - 2003) to the second (2004 - 2006). The logic behind this approach was that conversion from continuous grazing to TC grazing in C1 and C2 catchments only took place in 2001 when this project began. In order for TC grazing to have an impact, a minimum period of 3 years was assumed to be required. The 6 years of research was divided into the two 3-year periods to show the effect of TC grazing more clearly in the second period and treat the first one as the transition period. This type of comparison between the results for the two time periods should contain an element of uncertainty due to the temporal and spatial heterogeneity of rainfall characteristics. Nevertheless any significant changes in runoff and sediment transport in the second period as compared with the first period would be an indication of the effects of the grazing treatments.

The second approach was to plot the mass curves of runoff and sediment over the entire period of 2001 to 2006 using all the events for each catchment. This method was expected to identify the possible trend in runoff and soil loss through a long sequence of events.

In the third method of data analysis, the common events between the catchments (21 events) were selected to construct double mass curves of rainfall versus runoff and sediment. This arrangement of using only common events between the catchments provided a more rigorous and accurate comparison as it removes the noise caused by those rain events when data were missing or runoff did not occur from at least one of the catchments.

Mass and double mass curves are basic analytical tools which can be employed to identify significant changes in a variable in relation to time or to another variable. Any change or break in slopes of the curves could be related to various factors including an increase or a decrease in vegetation cover. Some of the mass/double mass curves developed for runoff and sediment yield in this research were best fitted by second order polynomial equations rather than linear ones. Polynomial regression analysis was used to determine if the curvilinear trends of the variables have a better fit of goodness compared with linear trends. With such analysis, the increase in $\mathrm{R}^{2}$ or decrease in SSE (sum of square of errors) from linear to quadratic regression examined employing the F-ratio ( $F$ statistic) and two separate degrees of freedom (of the numerator and the denominator, respectively) for comparison of the two models (Motulsky and Christopoulos 2004; McDonald 2008). For a small $p$-value of less than $\alpha$, the quadratic regression is preferred 
to linear regression which implies that the coefficient of the second order term is significantly different from zero and vice versa for higher $p$-values. This method of analysis emphasizes the extent to which the newly added second order term of the curvilinear model can significantly decrease the sum of square (SS) of the residuals.

The final method of analysis investigated the relationship between hydrologic variables (i.e. runoff depth, runoff coefficient, sediment concentration and sediment loss) and the ground cover levels associated with the two grazing systems for small and large events. Regression analysis was used to test for significant correlation between ground cover and hydrologic variables.

\section{Results}

The overall results show that a different number of runoff events (27 to 46) were recorded for the experimental catchments of TC and continuous grazing over the period from Jan 2001 to May 2006. The catchments C1 (TC grazing) and C3 (continuous grazing), received similar total rainfall over the entire duration of the study (Table 3) as well as over each of the two arbitrarily divided periods of 2001 to 2003 and 2004 to 2006 (Fig 3). The results shown in Table 3 illustrate a better runoff control and less soil erosion in $\mathrm{C} 1$ of TC grazing compared with C3 of continuous grazing. For instance, in C3 around $34 \%$ of the total rain turned into runoff from C3, while this proportion for C1 was less than $20 \%$. The runoff coefficient and sediment loss were also $72 \%$ and $125 \%$ higher in C3 than C1, respectively. The steeper catchment of TC grazing (C2), however generated the highest number of runoff events producing more runoff and soil loss than the other two catchments.

Table 3. Summary of the catchments responses to the grazing systems from 2001 to 2006

\begin{tabular}{|c|c|c|c|c|c|c|c|}
\hline \multirow[b]{2}{*}{ Treatments } & \multicolumn{3}{|c|}{ Total } & \multirow{2}{*}{$\begin{array}{c}\text { Runoff } \\
\text { coefficient }\end{array}$} & \multicolumn{2}{|c|}{ Sediment } & \multirow{2}{*}{$\begin{array}{l}\text { Total } \\
\text { runoff } \\
\text { events }\end{array}$} \\
\hline & $\begin{array}{l}\operatorname{rain}^{\#} \\
\mathrm{~mm}\end{array}$ & $\begin{array}{c}\text { EI30 } \\
\text { MJ/ha*mm/hr }\end{array}$ & $\begin{array}{l}\text { runoff } \\
\mathrm{mm}\end{array}$ & & $\begin{array}{l}\text { loss/runoff } \\
\mathrm{kg} / \mathrm{ha}{ }^{*} \mathrm{~mm}\end{array}$ & $\begin{array}{l}\text { loss } \\
\mathrm{kg} / \mathrm{ha}\end{array}$ & \\
\hline C1 TC grazing & 1383 & 14010 & 269 & 0.195 & 1.63 & 439 & 27 \\
\hline C2 TC grazing & 1943 & 15778 & 720 & 0.371 & 2.87 & 2064 & 46 \\
\hline C3 Con.grazing & 1341 & 13206 & 465 & 0.346 & 2.11 & 983 & 31 \\
\hline
\end{tabular}

\footnotetext{
${ }^{\#}$ Includes only the rain events contributing runoff generation
}

The differences shown in Table 3 could also be obtained from Fig 3 by comparing the results of the first period (2001 - 2003) with the second (2004 - 2006). These results for 
C1 of TC grazing show that both runoff and sediment decreased from the first period to the second despite $5 \%$ increase in total rain (Fig 3a) as well as $1 \%$ increase in rainfall erosivity (6962 to $7048 \mathrm{MJ} / \mathrm{ha} * \mathrm{~mm} / \mathrm{hr}$ ). Unlike C1, the C3 catchment of continuous grazing, experienced some increases in runoff depth and soil loss in the second period compared with the first (Fig 3c). Rainfall erosivity in C3 only decreased 1\% from the first period to the second period.

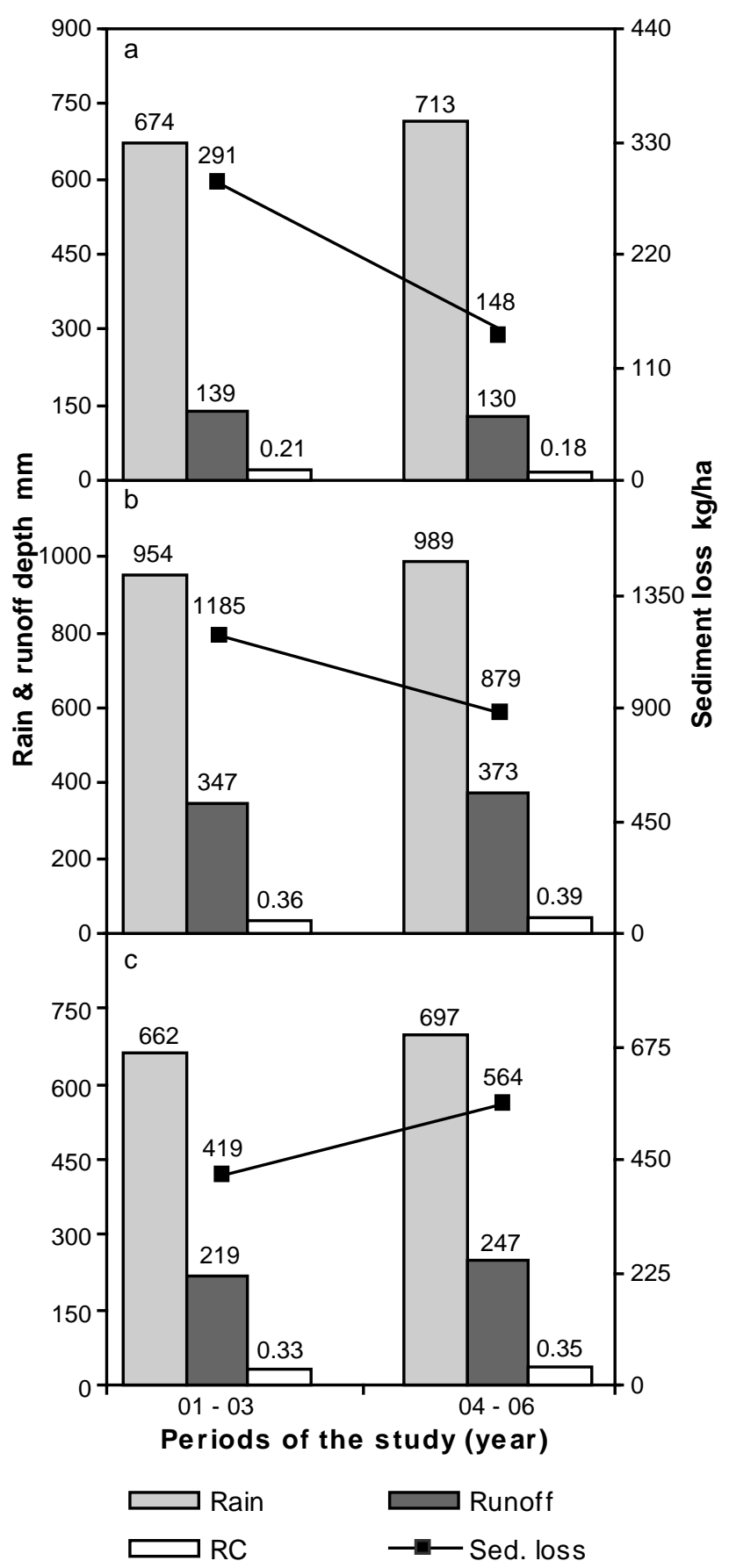

Fig. 3. Total rainfall and runoff depth, runoff coefficient (RC) and sediment loss over the first and second periods of study in C1 (a), C2 (b) and C3 (c) 
In the second catchment of TC grazing (C2), which is located on a steeper hill slope than $\mathrm{C} 1$, a lower amount of rain was required for runoff to generate. For this reason the number of runoff events increased and this may be one of the reasons for the increase in total runoff in the second period compared to the first (Fig 3b). However, despite its geomorphological differences with $\mathrm{C} 1$ and the same rainfall erosivity over the two periods (7885 to $7893 \mathrm{MJ} / \mathrm{ha} * \mathrm{~mm} / \mathrm{hr}$ ), total sediment loss declined from $1185 \mathrm{~kg} / \mathrm{ha}$ in the first period to $879 \mathrm{~kg} / \mathrm{ha}$ in the second period which is to some extend similar to that of C1.

\section{Mass/Double mass curve analysis}

The mass curves for rainfall, runoff and soil loss illustrate decreasing trends in runoff depth and sediment loss with time $(p<0.01)$ under TC grazing $(\mathrm{C} 1$, Fig $4 a)$. The regression analysis shows the runoff volume was best fitted by a negative second order polynomial equation, which indicates a lower proportion of rain being converted to runoff towards the end of the study period. Sediment loss was reduced at a higher rate than runoff depth throughout the experimental period in C1 (Fig 4a and Table 4).

The results for continuous grazing (C3) on the other hand showed no significant trend of change in runoff depth over time whereas a small increase in soil loss is obvious (C2, Fig $4 c)$. This positive quadratic trend $(p<0.10)$ is close to a linear relationship, indicating that the increase in the rate of sediment loss in the second period compared with the first is poorly significant (Table 4). 


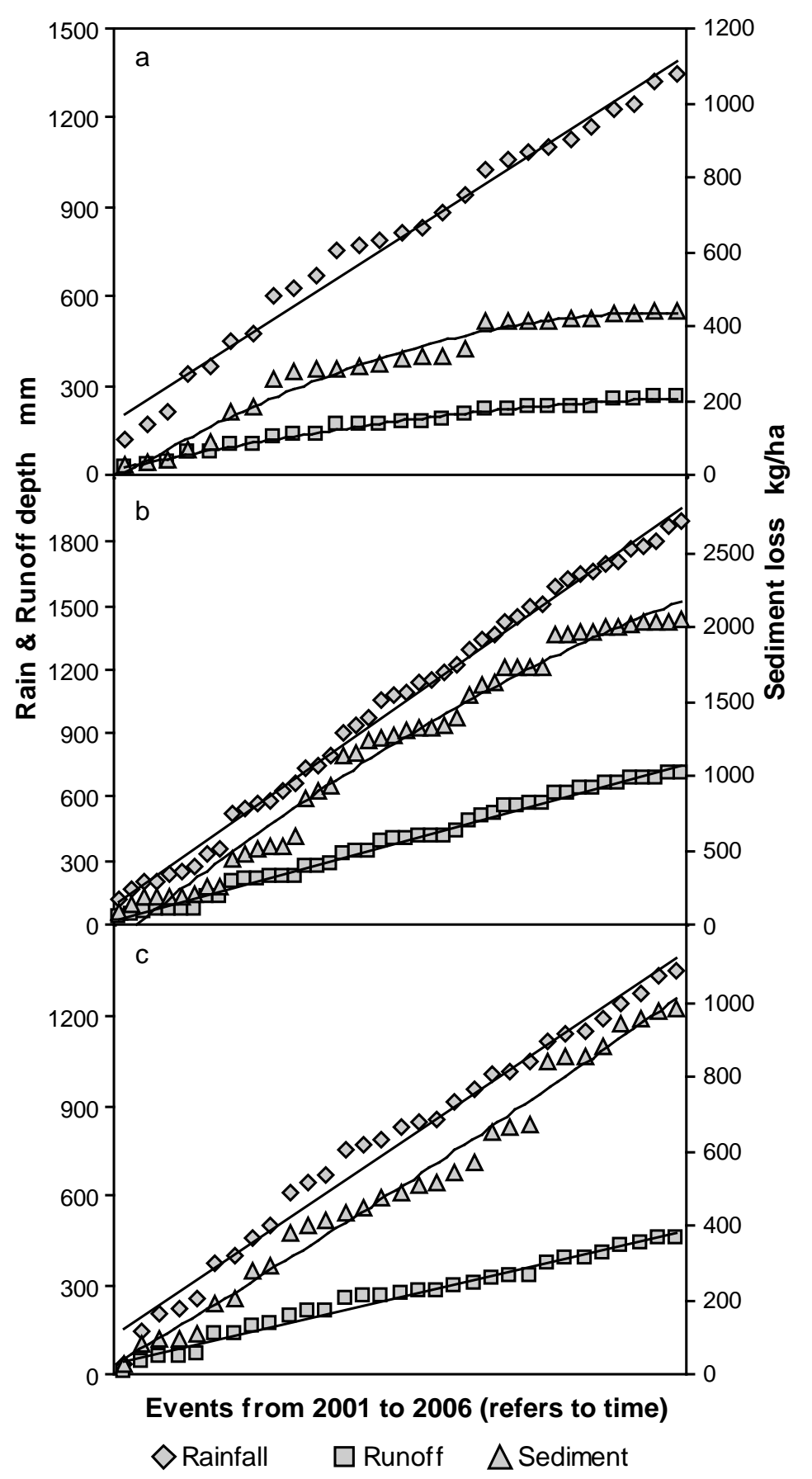

Fig. 4. Mass curves of rainfall, runoff depth and sediment loss using all the runoff events recorded from 2001 to 2006 in C1 (a), C2 (b) and C3 (c)

For C2 while the cumulative runoff is better described by a linear equation, the quadratic term is significant ( $p<0.01$, Fig $4 \mathrm{~b}$ ), suggesting a significant decrease in the soil loss. The decline in soil loss is pronounced towards the end of the study period, indicating the establishments of grass cover in this catchment similar to C1, albeit at a slower rate. 
Table 4. Polynomial regression analysis for runoff and soil loss

\begin{tabular}{|c|c|c|c|c|}
\hline Catchment name & Equations of best fit & $\mathrm{R}^{2}$ & $\mathrm{df}$ & $\mathrm{F}$ \\
\hline \multicolumn{5}{|c|}{ Mass curves of rainfall depth with time } \\
\hline C1 (TC grazing) & $Y=45.46 X+160.14$ & 0.98 & & \\
\hline C2 (TC grazing) & $Y=41.17 X+67.44$ & 0.99 & & \\
\hline C3 (Con. grazing) & $Y=41.52 X+113.74$ & 0.98 & & \\
\hline \multicolumn{5}{|c|}{ Mass curves of runoff depth with time } \\
\hline C1 (TC grazing) & $Y=-0.233 X^{2}+15.48 X+9.64$ & 0.99 & $2: 24$ & $96^{* * *}$ \\
\hline C2 (TC grazing) & $Y=16.135 X+8.13$ & 0.99 & & \\
\hline C3 (Con. grazing) & $Y=14.269 X+29.73$ & 0.98 & & \\
\hline \multicolumn{5}{|c|}{ Mass curves of sediment loss with time } \\
\hline C1 (TC grazing) & $Y=-0.646 X^{2}+34.7 X-29.41$ & 0.97 & $2: 24$ & $56 * * *$ \\
\hline C2 (TC grazing) & $Y=-0.39 X^{2}+68.66 X-158$ & 0.98 & $2: 43$ & $21.5 * * *$ \\
\hline C3 (Con. grazing) & $Y=+0.1036 X^{2}+29.1 X+10$ & 0.98 & $2: 28$ & $3.2 *$ \\
\hline \multicolumn{5}{|c|}{ Double mass curves of rainfall-runoff } \\
\hline C1 (TC grazing) & $Y=-0.0007 X^{2}+0.3 X-17.5$ & 0.99 & $2: 18$ & $108 * * *$ \\
\hline C2 (TC grazing) & $Y=0.489 X-16.34$ & 0.99 & & \\
\hline C3 (Con. grazing) & $Y=0.372 X-19.91$ & 0.99 & & \\
\hline \multicolumn{5}{|c|}{ Double mass curves of rainfall-sediment } \\
\hline C1 (TC grazing) & $Y=-0.0002 X^{2}+0.71 X-80.4$ & 0.98 & $2: 18$ & $21.5^{* * *}$ \\
\hline C2 (TC grazing) & $Y=-0.0003 X^{2}+1.93 X-209.7$ & 0.98 & $2: 18$ & $4^{* *}$ \\
\hline C3 (Con. grazing) & $Y=+0.0005 X^{2}+0.34 X+25.6$ & 0.98 & $2: 18$ & $15.7^{* * *}$ \\
\hline
\end{tabular}

A more accurate picture of the changes observed in runoff and soil loss over time could be obtained using double mass curves of rainfall versus runoff and sediment. Total rainfall for the 21 selected events was about the same for all three catchments with a small variation from 1137 to $1181 \mathrm{~mm}$.

From the double mass curves of rainfall-runoff (Fig 5a), only C1 catchment (TC grazing) showed a declining trend for runoff through time $(p<0.01)$. This indicated that under C1 a lower proportion of rain became runoff, being more noticeably over the second part of 
the study (since early 2004). For the other two catchments, however, neither C2 (TC grazing) nor $\mathrm{C} 3$ (continuous grazing) experienced such a change over time. Comparing responses of $\mathrm{C} 1$ and $\mathrm{C} 3$ showed that TC grazing was more effective in reducing runoff over time, in particular during the second period. Such a response could be a result of an increase in infiltration and interception by the higher level of ground and foliar cover.

The double mass curves of rainfall-sediment (Fig 5b) illustrate a more consistent decrease in soil loss over time than was the case for runoff for TC. It shows a reducing trend of sediment yield in both catchments of TC grazing (C1 and C2) over the second half events towards the end of the study period ( $p<0.01$ ). Unlike C1 and C2 (TC grazing), C3 (continuous grazing) showed an increasing trend in soil loss with cumulative rain, which is more pronounced in the last part of the second period of the study ( $p<0.01$, Table 4 ).

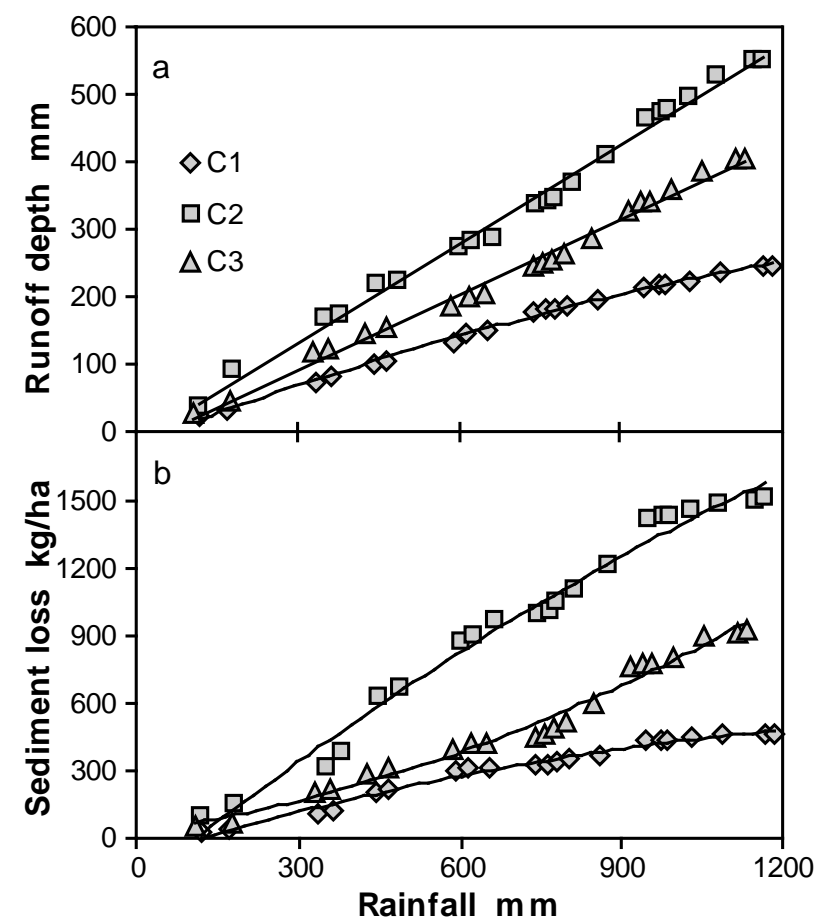

Fig. 5. Double mass curves of rainfall-runoff and rainfall-sediment for the catchments using the selected events from 2001 to 2006

\section{Ground cover}

The increase in ground cover in the TC grazing catchments has been hypothesized to be the reason for the decrease in runoff and soil loss observed in C1 and C2. In response to the grazing treatments, the experimental catchments showed different levels of ground cover over the period of the study. The records of ground cover for the 21 selected events (Fig 6) showed that the main differences between the catchments are from early 2004 
onwards which coincides with the decreasing trends in runoff and soil loss under TC grazing.

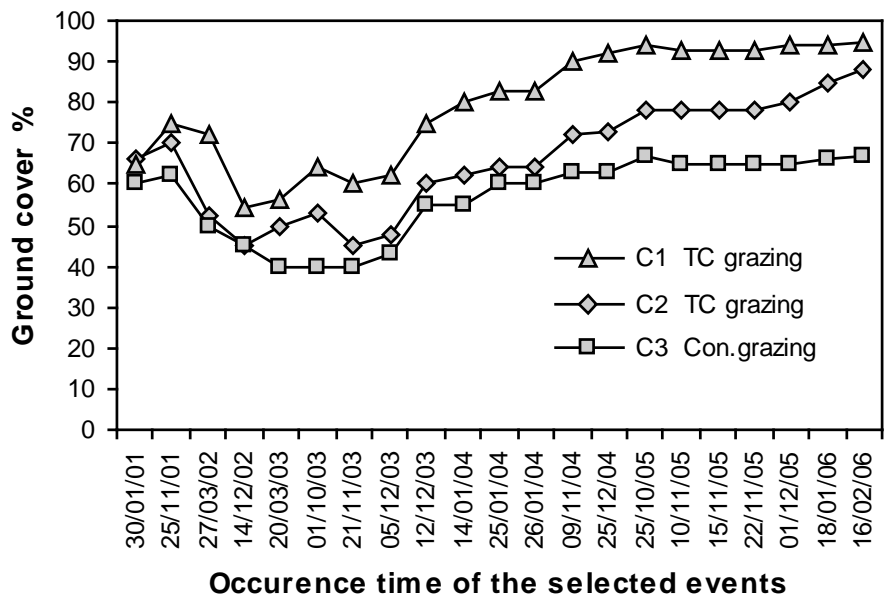

Fig. 6. Changes in ground cover at the time of the selected events in the experimental catchments

Ground cover in C1 (TC grazing) increased to about 75\% in early 2004, and reached as high as $90 \%$ by the end of the year, and remained at this level for the rest of the study period (Fig 6). Surface cover in the C3 catchment (continuous grazing) also improved in 2004 of relatively high rainfall year, reaching to around $65 \%$ but remained constant for the rest of the study period. Thus the difference between C1 and C3 continued to increase with time from the beginning of the project in 2001, reaching as high as $25 \%$ in 2006. Ground cover in C2 (TC grazing) which was around the same level as C3 at the early stage, lagged behind C1 initially, but increased in 2005 and 2006, almost catching up with $\mathrm{C} 1$ by the end of the study period.

\section{Ground cover in relation to the hydrologic variables}

The results presented indicate a strong link between the ground cover and the changes that occurred in runoff and soil loss in some of the catchments. To explore the extent to which these changes can be interpreted as being due to changes in ground cover, correlation analysis was carried out. The relationship between ground cover and the hydrologic variables (i.e. runoff coefficient, runoff depth, sediment concentration and soil loss) was examined for individual catchments for small and large runoff events.

\section{-Runoff coefficient / Runoff depth}

Graphical illustrations of the relationship between ground cover, runoff coefficient and runoff depth in C1 catchment (TC grazing) are presented in Fig 7. It shows that in general, runoff as well as runoff coefficient decreases as ground cover increases. However, the effect of ground cover on runoff is significant $(p<0.01)$ only for small events (Figs 7a \& 7b, Table 5). 
For large events, while the inverse relationship between the cover and runoff depth (Fig 7d) is recognizable, though insignificant, no such a relationship is found with respect to runoff coefficient (Fig 7c). The results show the overall decrease in runoff depth reported earlier for C1 of TC grazing (Figs 4a \& 5a) appear to be largely due to the small events and the effect of cover on runoff is quite limited for large events.

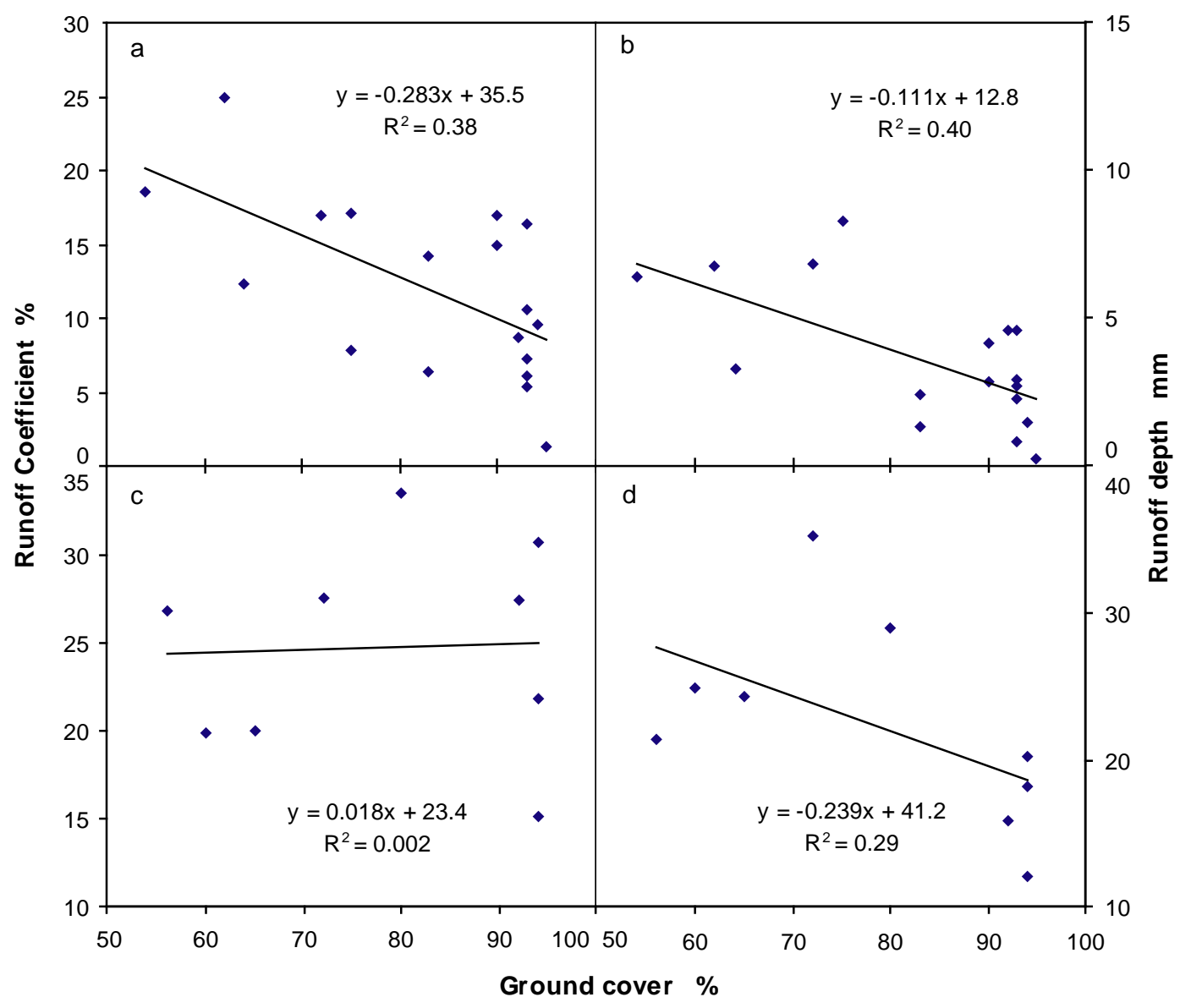

Fig. 7. Ground cover in relation to runoff coefficient and runoff depth in C1 catchment under the groups of small (a \& b) and large (c \& d) events

The responses of the other two catchments (C2 of TC grazing and C3 of continuous grazing) to ground cover in relation to runoff were shown to be insignificant (Table 5). Results for C2 and C3 confirm the earlier observation of little change in runoff depth over time (Figs 4c, 4b \& 5a). 
Table 5. Correlation coefficients between ground cover and runoff/sediment for the small and the large events

\begin{tabular}{|c|c|c|c|c|}
\hline & Small & large & Small & large \\
\hline & \multicolumn{2}{|c|}{ Runoff Coefficient } & \multicolumn{2}{|c|}{ Runoff Depth } \\
\hline C1 (TC grazing) & $-0.62 * * *$ & $0.05 n s$ & $-0.67 * * *$ & $-0.54 n s$ \\
\hline C2 (TC grazing) & $-0.20 n s$ & $0.06 n s$ & $-0.09 n s$ & $-0.34 n s$ \\
\hline \multirow[t]{2}{*}{ C3 (Con. grazing) } & $0.14 n s$ & $0.14 n s$ & $-0.02 n s$ & $-0.12 n s$ \\
\hline & \multicolumn{2}{|c|}{ Sediment Concentration } & \multicolumn{2}{|c|}{ Sediment Loss } \\
\hline C1 (TC grazing) & $-0.76^{* * *}$ & $-0.78 * * *$ & $-0.78 * * *$ & $-0.81 * * *$ \\
\hline C2 (TC grazing) & $-0.74 * * *$ & $-0.54 *$ & $-0.66 * * *$ & $-0.59 *$ \\
\hline C3 (Con. grazing) & $-0.22 n s$ & $-0.16 n s$ & $-0.21 n s$ & $-0.02 n s$ \\
\hline
\end{tabular}

\section{-Soil loss / Sediment concentration}

Soil loss in C1 of TC grazing was reduced as the surface cover increased. The decrease in sediment production given in Figs 4a and 5b (in particular after early 2004) was most likely related to the high level of surface cover produced and maintained over the second period of the study. The graphical relationship of surface cover with sediment concentration and soil loss confirm this hypothesis (Fig 8). 


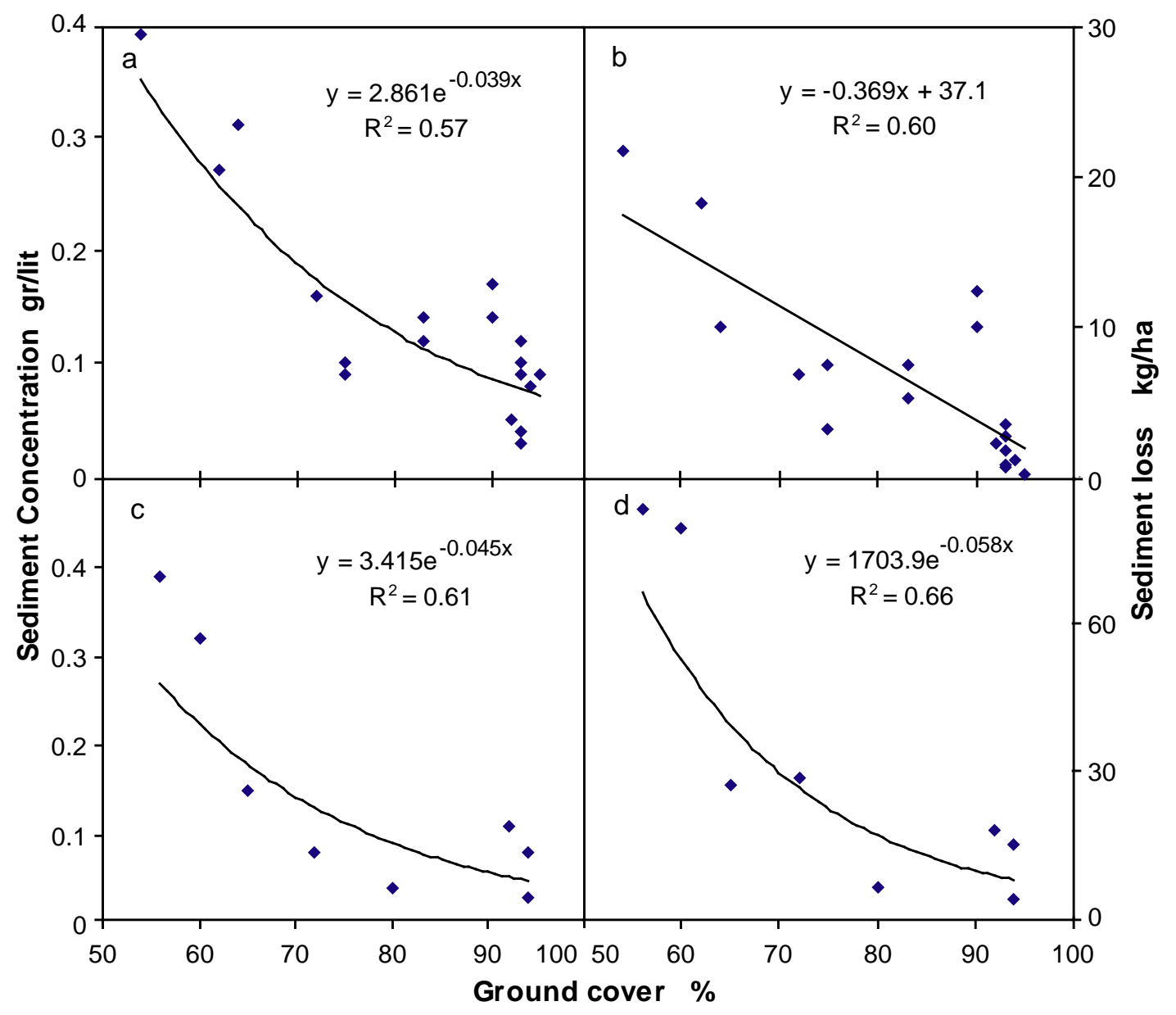

Fig. 8. Ground cover in relation to sediment concentration and sediment loss in C1 catchment under the groups of small ( $\mathrm{a}$ \& b) and large (c \& d) events

The Fig 8 shows linear and mostly exponential relationships for both small and the large groups of events. The analysis of the regression lines revealed strong correlations between the ground cover percentage and sediment concentration as well as soil loss $(p<$ 0.01, Table 5).

Overall results on sediment concentration and soil loss using all the events of different sizes, confirm that the relationship between the variables and ground cover is best described by an exponential regression type $(p<0.001)$. Catchment C1 (TC grazing) has produced sufficient sediment data under surface cover ranging from 55 to 95\%. Although a full range of surface cover of 0 to $100 \%$ would add more confidence to the results, nevertheless based on the data available, the ground cover level of $70 \%$ (Fig 9) is proposed as a safe minimum surface vegetative cover to be maintained by graziers in the region of Traprock. When cover levels fall below 70\%, both figures 9A and 9B show a rapid rise in sediment loss. 


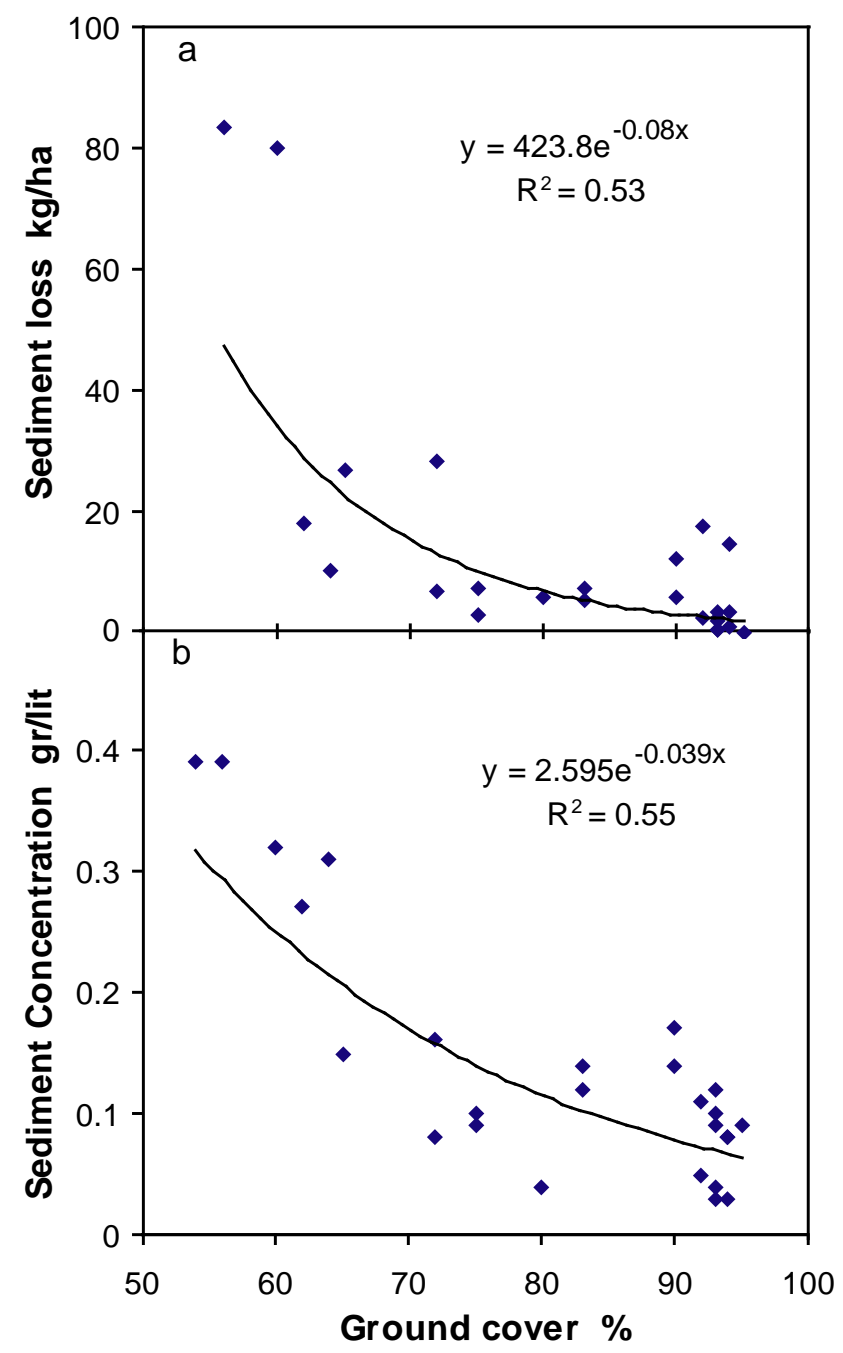

Fig. 9. The exponential relationship of cover levels with sediment loss (a) and sediment concentration (b) in C1 catchment

In C2 catchment of TC grazing, unlike the insignificant effects of cover on runoff presented earlier, both sediment concentration and sediment loss showed a significant correlation with ground cover (Table 5). For large events, poor but significant correlations were observed between the cover and sediment concentration/loss $(p<0.10)$. These relationships were more significant using the group of the small events $(p<0.01)$. The positive effect of ground cover on sediment reduction in C2 is mostly attributed to the increase in surface cover over the second period from after 2004 when the cover level exceeded $70 \%$ as the nominated safe threshold cover in the area. These results confirm the outcomes on sediment reduction obtained from mass/double mass curve analysis (Figs $4 b$ \& 5b). 
In the C3 catchment of continuous grazing no clear picture of correlation between ground cover and sediment was found for both small and large events (Table 5). This result is the same as it was already observed between cover and runoff variables showing very low correlations of coefficients and high variability in the slope of the fitted lines.

\section{Discussion}

The main results of this research in the study area showed how the new system of TC grazing enhances organic surface cover and decreases runoff and soil erosion compared with continuous grazing. The decrease in runoff and soil loss in TC grazing is largely attributed to the long rest period which is necessary for recovery of the plants defoliated by grazing animals. For instance, over the growth season of $2003-2004$, the two catchments of TC grazing were rested for 156 days, during which they received a total rainfall of $480 \mathrm{~mm}$. Such a coincidence of the rest period with multiple favorable conditions of rain and temperature resulted in a massive pasture production in 2004. This in turn provided the surface cover with a large quantity of organic matter to increase and reinforce the protective organic layer of soil surface even over the subsequent years.

A decrease in runoff and soil loss was also observed by Warren et al. (1986a) and Weltz and Wood (1986a; b) using the similar practice of high intensive short period grazing system. These authors attributed the increased infiltration and reduced soil erosion to the provision of a sufficient rest period, allowing a great accumulation of above and belowground organic matter and surface residue.

The different responses of the two catchments to TC grazing observed in this study highlight the variation in slope and soil characteristics and their major effects on hydrology and soil erosion. However despite such differences, C1 and C2 of TC grazing both showed a reduced soil loss relative to C3 with continuous grazing.

\section{Runoff and surface cover}

The Catchment C1 with TC grazing has been the only catchment to show some significant decrease in runoff under small runoff events (rain $<50 \mathrm{~mm}$ ) but not under the large ones (rain $>50 \mathrm{~mm}$ ). The runoff reduction for $\mathrm{C} 1$ suggests a higher rate of infiltration facilitated by the increase in surface cover being sustained over the second period of 2004 to 2006. Such an improved ground cover can maintain a high infiltration rate over a longer period of time during runoff events (Meyer et al. 1970; Freebairn and Wockner 1986a; b) leading to lower runoff and soil loss.

Runoff reduction could be also attributed to the increase in soil organic matter and the decrease in soil bulk density reported earlier under TC grazing (C1) (Sanjari et al. 2008) which encourage a higher rate of infiltration thus reducing runoff volume. This kind of organic material in the top layer of soil mostly originates from root growth and provides the soil with a large amount of vertically oriented pores produced after dying off, 
facilitating better infiltration (Jones 2000). The connection between soil organic matter, bulk density and surface cover with runoff generation and soil loss has been also emphasized under a plot scale experiment in semi-arid Spain (Albaladejo et al. 1998; Castillo et al. 1997)

The effectiveness of ground cover in controlling runoff and soil erosion is influenced by prevailing runoff generation mechanisms (Castillo et al. 2003). Under both mechanisms of infiltration/saturation excess overland flow, (when rainfall intensity exceeds the infiltration rate in soil profile or when infiltration amount exceeds soil water capacity of the top layer), runoff is generated irrespective of the level of ground cover. These kinds of runoff flows that are generated mostly under the large events in C1 (TC grazing), showed no clear relationship with surface cover. McIvor et al. (1995) reported that under small events, a minimum of $40 \%$ of cover was needed to reduce runoff, and as the size of the storms increased, greater level of cover was required for the reduction in runoff to take effect. In the large events, consistent with those of McIvor et al. (1995) and Puigdefabregas (2005), there was little or no effect of cover on runoff, indicating the contribution of both bare areas and vegetation cover as runoff sources, which mask the effect of ground cover.

The ground cover levels in the other two catchments were found to have no effect on runoff in neither $\mathrm{C} 2$ nor $\mathrm{C} 3$. In these catchments a combination of the runoff generation mechanisms as well as physiognomic features of the catchments and soil characteristics are probably responsible for runoff generation irrespective of the grazing systems. However a higher exposure of bare ground in C3, and to some extent in C2 increases the impacts of raindrops on surface aggregates resulting in subsequent sealing and crusting which reduces infiltration and increases runoff.

\section{Soil loss and surface cover}

The alternative system of TC grazing has greater effects on soil loss than on runoff. This became more evident when the analyses were carried out for two separate types of runoff events. The decrease in soil loss was significant following the application of TC grazing in the study area but more effectively in C1 than C2. The correlation analysis between sediment concentration/loss and cover showed that the decline in soil loss was greatly associated with the increase in ground cover. The result is consistent with those of Singer \& Blackard (1977) and Rose (1985a; b) in which the reduction in sediment concentration is directly attributed to the percentage of the soil surface protected from both raindrop impact and processes involved in surface runoff (entrainment and re-entrainment).

The relationships between surface cover and soil loss or sediment concentration are better described by an exponential regression model. This relationship suggests an approximate critical threshold of around $70 \%$ cover for the study area, below which soil erosion increases sharply with any decrease in the percentage of surface cover, and above which the effectiveness of cover in reducing erosion declines. In literature under different 
circumstances of catchment characteristics, soil types and vegetation, the cover thresholds of 30-40\% (Snyman and Van Rensburg 1986; Lawrence and Cowie 1992; Silburn et al. 1992; Zobisch 1993) and 70 - 75\% (Copeland 1963; Lang 1979; Costin 1980) have been suggested.

In a laboratory experiment, Rogers and Schumm (1991) quoted by Puigdefabregas (2005) showed exponential relationships between soil erosion and surface cover in both above and below a certain level of cover. Lang (1979) attributed such a significant increase in runoff and erosion below a critical level of cover to the bare ground patches that are increasingly connecting together, allowing a faster runoff flow and hence less time for infiltration. However above the critical threshold ground cover patches are more efficiently connected, leading to a significant decrease in runoff and erosion.

Hydrologic responses of grazing lands to the elevated ground cover has also been reported to greatly affected by plant spatial patterns as well (Abrahams et al. 1995; Ludwig and Tongway 1995) which in some cases may override the magnitude effect of the total surface cover (Bartley et al. 2006). For instance hillslopes with clumpy distribution of vegetation produced more runoff and soil loss than that with spatially uniform distribution (Boer and Puigdefabregas 2005). In a patch scale experiment, the same results of high runoff and sediment yield was observed when the plants patches were arranged in a clumped pattern despite having a high vegetation patch density (Bautista et al. 2007). These results show how spatial distribution of plant species affects the efficiency of ground cover in controlling runoff and soil loss in different landscapes in addition to the other major determinants (i.e. amount of surface cover/plant residue, rainfall characteristics, geomorphology and soil characteristics).

In C2 of TC grazing, reduction in soil loss achieved up to $25 \%$ over the second period of the study was somewhat unexpected since this catchment has larger areas of land with steeper slopes than C1 and C3 catchments. Decrease in soil loss under C2 can be attributed to the significant increase in ground cover from early 2005 onward. A high level of ground litter accumulation on this catchment (Sanjari et al. 2008) over the second period of the study appears to have contributed to the increased sediment trapping efficiency and reduces soil loss.

Unlike C1 catchment, no runoff reduction occurred in C2, thus the decrease in sediment concentration in this catchment was the only reason for the decline in soil erosion. The process which led to low sediment concentration seems to be the decrease in flow velocity under increasing surface cover (Cogo et al. 1983; 1984; Okwach 1988), thus reducing stream power and transport capacity (Kramer and Meyer 1969; Meyer and Mannering 1971).

Despite the results for C1 and C2, no correlation was found between ground cover and sediment concentration/load for the $\mathrm{C} 3$ catchment (continuous grazing) for both groups of small and large events. In this catchment, ground cover ranged from 40 to $65 \%$ and did 
not increase sufficiently over time to effectively reduce runoff and soil loss and hence a large proportion of soil surface remained unprotected against raindrop impact and overland flow. This situation actively contributes to the increase in runoff and soil loss particularly during large storms with high rainfall intensity. Furthermore the catchment C3 experienced long term trampling under continuous grazing, resulting in an increase in its bulk density (Sanjari et al. 2008), which has a direct effect on reducing infiltration rate causing more runoff and sediment loss.

In addition to the above statements for C3 catchment, there has been a short term animal exclusion (from mid July to mid November 2002) from the continuous grazing paddock that may have contributed to the increase in soil loss over the second period of the study compared with the first.

\section{Conclusion}

The results presented in this paper indicate that soil loss was reduced significantly under TC grazing compared with continuous grazing irrespective of the size of runoff events. This effect is more pronounced in areas low slope and greater soil depth. The results also suggests that runoff would be reduced during small events for TC grazing catchments where soils have better physical and geomorphological conditions and are protected by an effective layer of organic material. Time-controlled grazing appears to be more efficient in reducing the runoff with a deeper permeable soil profile, providing a higher soil moisture and water retention capacity, where a larger increase in soil organic material is expected to occur with TC grazing.

Results of this study also showed that ground cover is a key driver in reducing sediment concentration, resulting in significantly lower sediment loss under TC grazing. The new system of TC grazing presented a superior capability to produce and maintain a higher level of ground cover (up to 90\%) compared with continuous grazing (up to 65\%). A minimum of $70 \%$ of surface cover appeared to be a threshold level needed to efficiently protect the soil surface from erosive forces of rain and runoff.

\section{Acknowledgments}

The authors acknowledge Queensland Inglewood Landcare for their support and Natural Heritage Trust for the grant awarded to Cyril Ciesiolka. They also thank Rick and Louise Goodrich, the owners of the property as well as Mr. Eugene Creek for his assistance with field work. 


\section{References}

Abrahams AD, Anthony JP, Wainwright J (1995) Effects of Vegetation Change on Interrill Runoff and Erosion, Walnut-Gulch, Southern Arizona. Geomorphology 13, 37-48.

Albaladejo J, Martinez-Mena M, Roldan A, Castillo V (1998) Soil degradation and desertification induced by vegetation removal in a semiarid environment. Soil Use and Management 14, 1-5.

Alderfer RB, Robinson RR (1947) Runoff from pastures in relation to grazing intensity and soil compaction. Journal of the American Society of Agronomy 39, 948-958.

Bajracharya RM, Lal R (1998) Crusting effects on erosion processes under simulated rainfall on a tropical Alfisol. Hydrological Processes 12, 1927-1938.

Banasik K, Gorski D, Mitchell JK (2001) Rainfall erosivity for east and central Poland. In 'Soil erosion research for the 21st century'. Hawaii, USA. (Eds JC Ascough II, DC Flanagan). (American Society of Agricultural Engineers).

Bartley R, Roth CH, Ludwig J, McJannet D, Liedloff A, Corfield J, Hawdon A, Abbott B (2006) Runoff and erosion from Australia's tropical semi-arid rangelands: influence of ground cover for differing space and time scales. Hydrological Processes 20, 3317-3333.

Bautista S, Mayor AG, Bourakhouadar J, Bellot J (2007) Plant spatial pattern predicts hillslope semiarid runoff and erosion in a Mediterranean landscape. Ecosystems 10, 987-998.

Bermel KJ (1950) Hydraulic influence of modifications to the San Dimas critical depth measuring flume. Transactions of the American Geophysical Union 31, 763-768.

Boer M, Puigdefabregas J (2005) Effects of spatially structured vegetation patterns on hillslope erosion in a semiarid Mediterranean environment: a simulation study. Earth Surface Processes and Landforms 30, 149-167.

Boix-Fayos C, Calvo-Cases A, Imeson AC, Soriano-Soto MD, Tiemessen IR (1998) Spatial and short-term temporal variations in runoff, soil aggregation and other soil properties along a Mediterranean climatological gradient. Catena 33, 123138.

Brown LC, Foster GR (1987) Storm erosivity using idealized intensity distributions. Transactions of the ASAE 30, 379-386.

Bryant FC, Dahl BE, Pettit RD, Britton CM (1989) Does Short-Duration Grazing Work in Arid and Semiarid Regions. Journal of Soil and Water Conservation 44, 290296. 
Busby FE, Gifford GF (1981) Effects of livestock grazing on infiltration and erosion rates measured on chained and unchained pinyon-juniper sites in Southern Utah. Journal of Range Management 34, 400-405.

Calder IR, Kidd CHR (1978) A note on the dynamic calibration of tipping bucket gauges. Journal of hydrology 39, 353-356.

Castillo VM, Gomez-Plaza A, Martinez-Mena M (2003) The role of antecedent soil water content in the runoff response of semiarid catchments: a simulation approach. Journal of Hydrology 284, 114-130.

Castillo VM, MartinezMena M, Albaladejo J (1997) Runoff and soil loss response to vegetation removal in a semiarid environment. Soil Science Society of America Journal 61, 1116-1121.

Cogo NP, Moldenhauer WC, Foster GR (1983) Effect of Crop Residue, Tillage-Induced Roughness, and Runoff Velocity on Size Distribution of Eroded Soil Aggregates. Soil Science Society of America Journal 47, 1005-1008.

Cogo NP, Moldenhauer WC, Foster GR (1984) Soil Loss Reductions from Conservation Tillage Practices. Soil Science Society of America Journal 48, 368-373.

Copeland OL (1963) Land use and ecological factors in relation to sediment yields. In 'Proceedings Federal Inter-agency Sedimentation Conference'. Washington pp. 72-84. (USDA Miscellaneous Publication).

Costin AB (1980) Runoff and soil and nutrient losses from an improved pasture at Ginninderra, Southern Tablelands, New South Wales. Australian Journal of Agricultural Research 31, 533-546.

Dormaar JF, Smoliak S, Willms WD (1989) Vegetation and soil responses to shortduration grazing on fescue grasslands. Journal of Range Management 42, 252256.

Francis CF, Thornes JB (1990) Runoff hydrographs from three Mediterranean vegetation cover types. In 'Vegetation and Erosion'. (Ed. JB Thornes) pp. 363-384. (John Wiley and Sons: Chichester).

Freebairn DM, Wockner GH (1986a) A Study of Soil-Erosion on Vertisols of the Eastern Darling-Downs, Queensland .1. Effects of Surface Conditions on Soil Movement within Contour Bay Catchments. Australian Journal of Soil Research 24, 135158.

Freebairn DM, Wockner GH (1986b) A Study of Soil-Erosion on Vertisols of the Eastern Darling-Downs, Queensland .2. The Effect of Soil, Rainfall, and Flow Conditions on Suspended Sediment Losses. Australian Journal of Soil Research 24, 159-172. 
Giboire G, Soh A, Renmeester G, Bielders C, Persoons E (2003) Tipping bucket with splitter device to monitor runoff and suspended sediment charge. In '25 years of Assessment of Erosion Symposium'. Ghent, Belgium. (Eds D Gabriels, W Cormelis) pp. 231-237. (Ghent University).

Gifford GF, Hawkins RH (1978) Hydrologic impact of grazing on infiltration: a critical review. Water Resources Research 14, 305-313.

Greenwood KL, McKenzie BM (2001) Grazing effects on soil physical properties and the consequences for pastures: a review. Australian Journal of Experimental Agriculture 41, 1231-1250.

Greig-Smith P (1983) 'Quantitative plant ecology.' (WileyBlackwell: Oxford). Hutchinson MF (1995) Interpolating mean rainfall using thin-plate smoothing splines. International Journal of Geographical Information Systems 9, 385-403.

Jeffrey SJ, Carter JO, Moodie KB, Beswick AR (2001) Using spatial interpolation to construct a comprehensive archive of Australian climate data. Environmental Modelling \& Software 16, 309-330.

Johnston A (1962) Effects of grazing intensity and cover on the water-intake rate of fescue grassland. Journal of Range Management 15, 79-82.

Jones C (2000) Grazing management for healthy soils. In 'Stipa Inaugural National Grasslands Conference 'Better Pastures Naturally". Mudges, NSW, Australia. (Ed. CM Waters) pp. 68-75.

Kramer LA, Meyer LD (1969) Small amount of surface mulch reduce soil erosion and runon velocity. Transaction of the American Society of Agricultural engineering 12, 638-645.

Lang RD (1979) The effect of ground cover on surface runoff from experimental plots. The Journal of the Soil Conservation Service of New South Wales 35, 108-114.

Lawrence P, Cowie B (1992) Water balance and decline in soil fertility of brigalow pastures: outcomes and lessons from the brigalow catchment study. Queensland Department of Primary Industries No. RQR92007.

Ludwig JA, Tongway DJ (1995) Spatial-Organization of Landscapes and Its Function in Semiarid Woodlands, Australia. Landscape Ecology 10, 51-63.

Maher JM (1996) 'Understanding and managing soils in the stanthorpe-rosenthal region.' (Department of natural resources: Brisbane).

McDonald JH (2008) 'Handbook of Biological Statistics.' Available at http://udel.edu/ mcdonald/statintro.html accessed on Feb 2008. 
McGinty WA, Smeins FE, Merrill LB (1979) Influence of soil, vegetation, and grazing management on infiltration rate and sediment production of Edwards Plateau rangeland. Journal of Range Management 32, 33-37.

McIvor JG, Williams J, Gardener CJ (1995) Pasture Management Influences Runoff and Soil Movement in the Semiarid Tropics. Australian Journal of Experimental Agriculture 35, 55-65.

Meyer LD, Mannering JV (1971) The influence of vegetation and vegetative mulches on soil erosion. In 'The third international seminar for hydrology professors'. Indiana pp. 355 - 366. (Purdue University).

Meyer LD, Wischmeier WH, Foster GR (1970) Mulch rates required for erosion control on steep slopes. Soil Science Society of America Proceedings 34, 928-931.

Motulsky H, Christopoulos A (2004) 'Fitting Models to Biological Data using Linear and Nonlinear Regression.' (Oxford University Press: USA).

Mwendera EJ, Saleem MAM (1997) Infiltration rates, surface runoff, and soil loss as influenced by grazing pressure in the Ethiopian highlands. Soil Use and Management 13, 29-35.

Okwach G (1988) Effects of surface cover and land slope on sediment concentration and characteristics under different erosion processes. MS thesis, Griffith University.

Pan CZ, Shangguan ZP (2006) Runoff hydraulic characteristics and sediment generation in sloped grassplots under simulated rainfall conditions. Journal of Hydrology 331, 178-185.

Proffitt APB, Jarvis RJ, Bendotti S (1995) The Impact of Sheep Trampling and Stocking Rate on the Physical-Properties of a Red Duplex Soil with 2 Initially Different Structures. Australian Journal of Agricultural Research 46, 733-747.

Puigdefabregas J (2005) The role of vegetation patterns in structuring runoff and sediment fluxes in drylands. Earth Surface Processes and Landforms 30, 133147.

Rauzi F, Hanson DL (1966) Water intake and runoff as affected by intensity of grazing. Journal of Range Management 19, 351-356.

Rhoades ED, Locke LF, Taylor HM, Mcllvain EH (1964) Water intake on a sandy range as affected by 20 years of differential cattle stocking rates. Journal of Range Management 17, 185-190.

Rogers RD, Schumm SA (1991) The effect of sparse vegetation cover on erosion and sediment yield. Journal of Hydrology 123, 19-24.

Rose CW (1985a) Developments in soil erosion and deposition models. Advances in Soil Science 2, 1-63. 
Rose CW (1985b) Progress in research on soil erosion processes and a basis for soil conservation practices. In 'Soil Erosion Management'. Losbanos, Philippines. (Eds ET Craswell, JV Remenyi, LG Nallana) pp. 32-41. (ACIAR).

Sanjari G, Ghadiri H, Ciesiolka CAA, Yu B (2008) Comparing the effects of continuous and time-controlled grazing systems on soil characteristics in Southeast Queensland. Australian Journal of Soil Research 46, 348-358.

Silburn DM, Carroll C, Ciesolka CAA, Hairsine P (1992) Management effects on runoff and soil loss from native pasture in central Queensland. In 'The 7th Biennial Conference of the Australian Rangeland Society'. Cobar, New South Wales pp. 294-295.

Singer MJ, Blackard J (1977) Evaluation of wild oat straw as a soil erosion retardant using simulated rainfall. Agronomy Journal 69, 811-814.

Snyman HA, Van Rensburg WLJ (1986) Effect of slope and plant cover on run-off, soil loss and water use efficiency of natural veld. Journal of the Grassland Society of South Africa 3, 153-158.

Wahba G, Wendelberger J (1980) Some new mathematical methods for variational objective analysis using splines and cross validation. Monthly Weather Review 108, 1122-1143.

Warren SD, Nevill MB, Blackburn WH, Garza NE (1986a) Soil Response to Trampling under Intensive Rotation Grazing. Soil Science Society of America Journal 50, 1336-1341.

Warren SD, Thurow TL, Blackburn WH, Garza NE (1986b) The Influence of Livestock Trampling under Intensive Rotation Grazing on Soil Hydrologic Characteristics. Journal of Range Management 39, 491-495.

Weltz M, Wood MK (1986a) Short-Duration Grazing in Central New-Mexico - Effects on Sediment Production. Journal of Soil and Water Conservation 41, 262-266.

Weltz M, Wood MK (1986b) Short Duration Grazing in Central New-Mexico - Effects on Infiltration Rates. Journal of Range Management 39, 365-368.

Wills AK (1979) 'The Granite and Traprock area of South East Queensland. Part I - Land inventory.' (Queensland Department of Primary Industries: Brisbane).

Wood MK, Blackburn WH (1981) Grazing Systems: Their Influence on Infiltration Rates in the Rolling Plains of Texas. Journal of Range Management 34, 331-335.

Yu B, Ciesiolka CAA, Rose CW, Coughlan KJ (1997) Note on sampling errors in the rainfall and runoff data collected using tipping bucket technology. Transactions of the ASAE 40, 1305-1309. 
Yu B, Rosewell CJ (1996a) An assessment of a daily rainfall erosivity model for New South Wales. Australian Journal of Soil Research 34, 139-152.

Yu B, Rosewell CJ (1996b) Rainfall erosivity estimation using daily rainfall amounts for South Australia. Australian Journal of Soil Research 34, 721-733.

Zhou Q (1998) On the ground estimation of vegetation cover in Australian rangelands. International Journal of Remote Sensing 19, 1815 -1820.

Zobisch MA (1993) Erosion Susceptibility and Soil Loss on Grazing Lands in Some Semiarid and Subhumid Locations of Eastern Kenya. Journal of Soil and Water Conservation 48, 445-448. 